\title{
Przestrzenno-materialny krajobraz obozu koncentracyjnego
}

\author{
Łukasz Posłuszny
}

Uniwersytet Wrocławski

DOI: http://dx.doi.org/10.18778/1733-8069.16.1.08

Słowa kluczowe: przestrzeń, materialność, krajobraz, obóz koncentracyjny, instytucja totalna

\begin{abstract}
Abstrakt: W prezentowanym artykule podejmuję problem konstrukcji instytucji totalnej, analizując jej aspekt przestrzenno-materialny. Przedmiotem analizy jest obóz koncentracyjny na Majdanku (KL Lublin), natomiast teoretyczną skrzynkę narzędziową stanowi podejście biograficzne użyte do analizy przestrzeni oraz materialności. Artykuł składa się z trzech głównych komponentów. Rozpoczyna go rekonstrukcja metodologii badań, w której wyjaśniam teoretyczne podłoże pracy i dwa warianty sposobu badania biografii - przestrzeni i rzeczy - oraz określam ramy materiału badawczego i sposób jego interpretacji. Następnie przechodzę do problemu przestrzenno-materialnej historii obozów i konstrukcji Majdanka, rozpoczynając od analizy historii i wzorów organizacji przestrzennej obozów koncentracyjnych, poprzez refleksję nad ich symbolicznym aspektem, po ostatnią część, ujmującą obóz w kategoriach ekologicznych.
\end{abstract}

Łukasz Posłuszny, adiunkt w Zakładzie Socjologii Kultury i Cywilizacji Uniwersytetu Wrocławskiego. Jego zainteresowania koncentrują się w obszarze badań nad socjologią przestrzeni i materialności (przedmiotów), pamięcią oraz codziennością. Autor książki Przestrzenne formy upamiętniania Zagłady (2014).

\section{Adres kontaktowy:}

Instytut Socjologii

Uniwersytet Wrocławski

Koszarowa 3

51-149 Wrocław

e-mail: lukasz.posluszny@uwr.edu.pl

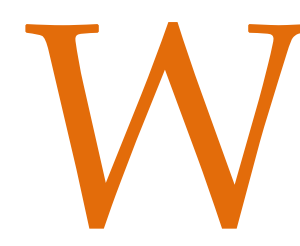

ostatnich $^{1}$ latach można zaobserwować proces zmiany orientacji nauk społecznych i humanistycznych. Wiąże się to z przekonaniem, że świat człowieka stanowi wypadkową licznych i niebranych wcześniej pod uwagę determinujących go sił, dlatego też w badaniach coraz częściej stara się je wyróżniać i włączać do analiz otaczającej rzeczywistości. Między innymi na bazie tych założeń

\footnotetext{
${ }^{1}$ Publikacja finansowana w ramach programu Ministra Nauki i Szkolnictwa Wyższego pod nazwą "Narodowy Program Rozwoju Humanistyki” w latach 2016-2019: Projekt „Kulturowe studia krajobrazowe" nr 0059/NPRH4/H2b/83/2016.
} 
rodziły się wysiłki badaczy reorientujące podejścia dyscyplinarne i nazywane zwrotami (turns). Niemiecka kulturoznawczyni Bachmann-Medick (2012) poświęciła im monografię, mówiąc o zwrotach językowym i interpretatywnym, performatywnym, refleksyjnym, postkolonialnym, translatorycznym, przestrzennym spacjalnym (ang. spatial) oraz ikonicznym. Ich liczba nie jest skończona, świat teorii pozostaje otwarty na nowe turns, choć - podobnie jak ma to miejsce $\mathrm{w}$ przypadku pojęć - nie każdy zwrot okazuje Popperowski „hart” i może trafić na zakurzoną półkę gmachu produkcji akademickiej. Zwroty należy zatem traktować jak poznawcze rozszerzenia, które z jednej strony rewidowały pole dotychczasowych badań, wzbogacając je o nowe perspektywy i podważając dyscyplinarne punkty ciężkości. Z drugiej natomiast rozciągały je na kolejne niezagospodarowane obszary, dostarczając ożywczej energii do dalszych poszukiwań. Dynamikę zwrotów można rozumieć także w kontekście zmian o charakterze endogennym, jako proces rosnących anomalii, „zamiatania pod dywan” i zmian paradygmatów opisywany przez Kuhna w polu nauki, oraz egzogennym, czyli inspiracji wypływających z tego, co dzieje się ze światem.

W takim kontekście trzeba byłoby umieścić zwrot ku przestrzeni oraz rzeczom i materialności (Preda 1999; Domańska 2006; Henare, Holbraad, Wastell 2007; Hicks 2010), rozumianym jako kolejne perspektywy, które być może należy lepiej zintegrować z wiodącym korpusem teorii społecznych lub potraktować jako kategorię uwrażliwiająca. Inspirując się tymi zwrotami, usiłuję w artykule zestawić przestrzenno-materialny wymiar organizacji z koncepcją instytucji totalnej (Goffman 2011; Posłuszny 2017a), biorąc na warsztat przypadek obozu koncentracyjnego na Majdanku (KL Lublin). Interesuje mnie to, jak skonstruowana jest przestrzeń obozu, jak można wyznaczyć jej granice oraz w jakim stopniu aspekt materialny przestrzeni wiąże się z funkcjonowaniem instytucji totalnej. Nie skupiam uwagi na, skądinąd niezwykle zajmującym, aspekcie krajobrazu obozu związanego ze środowiskiem i przyrodą (Małczyński 2015; 2017).

\section{Metodologia}

W prezentowanym artykule wykorzystuję podejście związane z badaniem przestrzeni oraz kulturowej biografii rzeczy. Biografię przestrzeni odnoszę do studiów krajobrazowych, gdzie bada się znaki obecności wielu ludzkich generacji, nakładających się na siebie $\mathrm{w}$ formie palimpsestu (Sendyka 2013). Badając poszczególne warstwy, należy zwrócić uwagę nie tylko na materialne pozostałości, ale także na ich wymiar społeczno-kulturowy. $\mathrm{Z}$ tego powodu należy mówić o trzech wymiarach biograficznych, które stają się przedmiotem refleksji w tym artykule. Pierwszy, fizyczny, badany przez tradycyjną geografię oraz empirycznie i pozytywistycznie nastawione poszukiwania można określić materiobrazem (matterscape). Drugi, społeczny, lustrujący niewidzialny świat wartości, norm i znaczeń, który przeszywa pierwszy wymiar krajobrazu, nazywa się socjobrazem lub władzobrazem (socioscape, powerscape). Trzeci, jednostkowy - psychobraz (mindscape) - jest badany przez psychologów środowiskowych i dotyczy sposobu postrzegania oraz odczuwania krajobrazu (Kolen, Renes 2015). Z kolei ostatni komponent prezentowanego podejścia to kulturowa biografia rzeczy, zwracająca uwagę na zmieniające się znaczenie obiektów materialnych w czasie (Appadurai 1986, Posłuszny 2015; 2017b; 2019). Pozwala to, tak jak w przypadku ludzi, mówić o życiorysach czy karierach rzeczy, które budują własną biografię, zmieniają role oraz statusy pod wpływem rozmaitych jednostkowych podejść 
do wytworów kultury materialnej, kolejnych klasyfikacji obiektów w obrębie wspólnoty i zmian dotychczasowych kontekstów (Kopytoff 2004; Hodder 2012). Wzory biograficzne, rozumiane jako sposoby włączania, ulokowania i przemieszczania rzeczy w obrębie zbiorowości, nazywać można stylami życia przedmiotów (Krajewski 2013).

W przypadku prowadzonych badań analiza materiałów zastanych zasadzała się z jednej strony, na dostępnym $\mathrm{w}$ szerokim obiegu korpusie opublikowanych tekstów oraz materiałach audio-wizualnych, z drugiej natomiast na źródłach niedostępnych szerokiej publiczności, zdeponowanych w archiwach. Podstawowe archiwa, z których korzystałem, to Archiwum Państwowego Muzeum na Majdanku (zasoby: Zbiór pamiętników, relacji i ankiet byłych więźniów, VII; Plany obozu koncentracyjnego na Majdanku oraz plany Muzeum, IX; Zbiór fotografii, XVII; Akta Polsko-Sowieckiej Komisji do Zbadania Zbrodni Niemieckich popełnionych na Majdanku, XXV [Wójcik 2012]) oraz Archiwum Żydowskiego Instytutu Historycznego w Warszawie (zasoby: Inwentarz zbioru Obozy, 209; Mapy, 245).

Zebrane materiały analizowałem przede wszystkim przy pomocy oprogramowania MAXQDA. Zdjęcia dokumentów łączyłem w pojedyncze pliki, a następnie wgrywałem do bazy programu. Przy kodowaniu korzystałem $\mathrm{z}$ jednej strony $\mathrm{z}$ techniki kodowania otwartego, aby pozostać czujnym i gościnnym na tematy mogące się wyłonić w toku czytania, z drugiej natomiast tematów i wątków, które wyklarowały się wcześniej w trakcie wcześniejszych prac terenowych. Korzystałem także z notatek oraz not, które spisywałem w programie podczas kodowania, przy okazji kwerend oraz rozmów z pracownikami.

\section{Skrócona historia obozu koncentracyjnego}

Klaus Mühlhahn (2010) wyróżnia trzy momenty w historii, które miały kluczowe znaczenie dla wykrystalizowania się modelu obozów koncentracyjnych jako instytucji służących inkarceracji. Pierwszy z nich to okolice 1900 roku, kiedy przez około dekadę powstają obozy na terenach podległych mocarstwom kolonialnym. Drugi to okres pierwszej wojny światowej, gdy obozy testowane w odległych zakątkach świata instalowane są teraz na rodzimym, europejskim gruncie. Ostatni moment to czas międzywojenny, w którym następuje radykalne rozpowszechnienie się tej formy instytucji totalnej na całym świecie.

Historia obozów koncentracyjnych rozpoczyna się w kontekście tłamszenia zrywów niepodległościowych przez imperia kolonialne w XIX i XX wieku. Bezpośrednim celem mocarstw było dławienie powstań, ale środkiem do osiągnięcia celu stał się terror wobec ludności cywilnej. Jak pokazuje zarazem przykład niemiecki w Afryce zachodniej, sytuacja zniewolenia stworzyła okazję, aby uwięzioną ludność dodatkowo wykorzystać do pracy oraz badań naukowych. Moment ten jest być może kluczowy dla zrozumienia dalszego rozwoju tej instytucji totalnej oraz jej relacji z systemem wiedzy-władzy. Wtedy również zidentyfikowano konsekwencje uwięzienia dużych grup ludności na małej przestrzeni, takie jak problemy sanitarno-higieniczne, rozwoje chorób i wysoką śmiertelność.

Obozy jenieckie stanowiły kolejne laboratorium, w którym doskonalono zarządzanie masami ludzi na wielką skalę. Tutaj też zdecydowano się bez ogródek na łamanie praw jeńców, wyzysk ekonomiczny prowadzący do śmierci, drastyczny rygor i znęcanie 
się. Zarazem jednak obóz zmieniał się materialnie, gdyż walczono z chorobami, instalowano łaźnie i pralnie do dezynfekcji, używano drutów kolczastych i ogrodzenia pod wysokim napięciem czy transportowano jeńców do prac publicznych oraz rolnych poza obóz, często przy użyciu kolei. Chociaż opisanych tu przykładów rozwiązań prawnych, technicznych i logistyczno-infrastrukturalno trudno nie zauważyć później w kontekście rozwoju obozów koncentracyjnych w latach 30. (Bartov 1996), to badacze zjawiska są raczej ostrożni w bezpośrednim łączeniu obydwu fenomenów. Mówi się w tym przypadku częściej o stworzeniu właściwego kontekstu niż prototypu dla późniejszych działań (Thiel 2013; Wachsmann 2016).

Dwa największe systemy obozów koncentracyjnych stworzyli najpierw sowieci i naziści, ale z biegiem lat powstawały one $w$ innych krajach, jak Japonia, Chiny, Korea Północna, Kambodża, Kenia, Algieria, Argentyna, Chile czy USA (Mühlhahn 2010). Pomimo tego, że nazistowskie obozy koncentracyjne istniały nieco ponad dekadę, ich historia jest burzliwa i pełna zwrotów akcji. Wachsmann (2016) wyróżnia aż sześć okresów, kiedy dokonywały się opisywane przemiany. Są to: (1) wczesne obozy (1933-1934), (2) formowanie i koordynacja (1934-1937), (3) rozbudowa (1937-1939), (4) wojna i masowe zabijanie (1939-1941), (5) ekonomia i eksterminacja (19421944), (6) apogeum i rozpad (1944-1945).

Pierwsze nazistowskie obozy były konstruowane naprędce i chaotycznie. Dekret o areszcie ochronnym umożliwił łatwe i szybsze aresztowania setek oponentów nowego systemu, ale zrodził zarazem problem infrastrukturalny, ponieważ więzienia i domy poprawcze nie mogły pomieścić rosnącej w zastraszającym tempie liczby aresztantów. $Z$ tego powodu władze państwowe, regionalne i lokalne sankcjo- nowały powstawanie obozów w najdziwniejszych miejscach, gdzie nad więźniami kontrole sprawowały bardzo różne formacje - od strażników więziennych do bojówkarzy SS i SA. Od chwili, gdy kontrole nad nimi przejął Eicke oraz SS, rozpoczęło się systematyczniejsze wytwarzanie reguł. Dotyczyło ono formowania wewnętrznej przestrzeni interakcji za sprawą regulaminów i szkoleń, ale również rozlokowywania i kształtowania obozów. W drugim etapie rozwoju, to jest w latach 1934-1937, obok Dachau i Lichtenburga powstają obozy Buchenwald i Sachsenhausen, budowane na nową modłę - oddalone od miast, z rzędami baraków i wież strażniczych, własną infrastrukturą drogowa, elektryczną i kanalizacyjną (Kamiński 1990; Wachsmann 2016). Pojawia się w nich praca, ale wciąż podporządkowywana jest ona częściej funkcji zastraszania aniżeli wytwarzania. Zmienia się to w latach 1937-1939, gdy SS powołuje Spółkę Niemieckich Robót Ziemnych i Kamieniarskich, mającą za zadanie dostarczać surowców budowlanych na potrzeby modernizacyjnego projektu Rzeszy. Z tego powodu zakładane wtedy obozy Flossenbürg i Mauthausen powstają w sąsiedztwie kamieniołomów (podobnie będzie z Gross Rosen i Natzweiler), a w okolicy Buchenwaldu i Sachsenhausen stawia się cegielnie (Sofsky 2016; Wachsmann 2016). Wtedy też do obozów zaczynają trafiać masy więźniów niepolitycznych, co uwypukla tylko wzrastająca pozycję pracy w systemie obozowym, usankcjonowaną formalnie w marcu 1942 roku, gdy obozy zmieniły organizacyjną afiliację - z jednostki bezpieczeństwa (RSHA) na jednostkę gospodarczą (SS-WVHA). W międzyczasie, po rozpoczęciu działań wojennych w Polsce i Związku Radzieckim, zaczęła ziszczać się wizja kolonizacyjna Niemiec, powiązana z koncepcją poszerzania przestrzeni życiowej. Dlatego w tym okresie obserwuje się dwie tendencje $\mathrm{w}$ obozach. Pierwsza to eksperymenty z masowym uśmiercaniem, wykonywane przez lekarzy 
i naukowców związanych z akcją T4 w szpitalach psychiatrycznych. Druga natomiast to plany wielkiej rozbudowy obozów na kształt pseudomiast, zarówno ich części mieszkalnych, jak i produkcyjnych. Jednak w rezultacie zamiast koncentracji obserwuje się rozproszenie i rozbudowę obozów satelickich w miejscach lub okolicach zapotrzebowania na pracę, która w ostatniej fazie służy przede wszystkim przemysłowi zbrojeniowemu.

Podsumowując, usytuowanie obozów miało związek z ich funkcjami, czyli z terrorem, pracą i eksterminacją oraz ograniczeniami techniczno-materialnymi. Ponieważ funkcje ulegały zmianie, w zależności od okresu można dostrzec różnice $\mathrm{w}$ urzeczywistnianiu idei obozów. Ponadto każda z wyżej wskazanych funkcji miała swoje warianty. Niekiedy obóz koncentracyjny powstawał w okolicach terenów uprzemysłowionych lub mających się takimi stać, gdzie wydobywano surowce i produkowano towary, a innym razem w strategicznym miejscu logistycznym, gdzie istniała populacja lub przestrzeń do wytwórczego skolonizowania. Wówczas to produkcję lokowano w pobliżu obozu i populacji, a nie na odwrót. W przypadku Majdanka, obozu na wschodniej granicy wpływów Rzeszy, jego funkcja miała inkorporować rosnącą populację jeńców i więźniów z ZSRR, a także wspierać akcję germanizacyjną regionu Lubelszczyzny (Wachsmann 2016). Z kolei obozy zagłady, podporządkowane eksterminacji, starano się ukrywać przed opinią publiczną w lasach, wykorzystywano granice naturalne, jak bagno czy rzekę, ale również kreowano nowe bariery, jak ogrodzenia i maskowano teren gałęziami, płotami oraz drzewami (Mańkowski 1991; Knowles, Jaskot 2014). Podobnie było z obozami koncentracyjnymi, tylko że te ostatnie musiały realizować cele wytwórcze, stąd połączone siecią z systemem produkcji - nie mogły być aż tak odizolowane.
Obszar pod budowę kompleksu obozowego w Lublinie zlokalizowano od południowej strony szosy prowadzącej do Zamościa, a dalej do Lwowa, $5 \mathrm{~km}$ od centrum miasta i nieopodal węzła kolejowego, skąd wcześniej wysiedlono kilku mieszkańców i co było praktyką powszechną (Węgrzyn 2015). Teren obozu opada w kierunku drogi, co sprawia, że jest on znakomicie widoczny. $Z$ tej strony graniczy on z Majdanem Tatarskim, dzielnicą od której wzięła się już w 1941 roku zwyczajowa nazwa lagru, to jest małego majdanu, czyli Majdanka. Oficjalnie do 1943 roku przetrwała pierwsza jego nazwa „Obóz jeniecki Lublin” (Kriegsgefangenenlager der Waffen SS Lublin, w skrócie KGL Lublin), zastąpiona następnie przez Obóz koncentracyjny Lublin (KL Lublin). Miasto graniczyło z obozem od zachodniej oraz częściowo południowej strony, od wschodniej natomiast rozpościerały się pola, a około $10 \mathrm{~km}$ dalej Las Krępiecki, w którym dokonywano masowych egzekucji. Obóz był zatem granicą. Z jednej strony na nim kończyło się miasto, a za nim znajdowały już tylko pola, z drugiej natomiast pozostawał on w styczności nie tylko przestrzennej, ale i technicznej czy społecznej z miejskim organizmem. W czerwcu 1942 roku władze miejskie wyraziły zgodę na podłączenie. Zbudowano wtedy ciągi komunikacyjne, rowy odwaniające, betonowe przejścia (Marszałek 1987; Mańkowski 1991; Sofsky 2016).

Warto jeszcze wspomnieć o dwuznaczności związanej z lokowaniem obozów koncentracyjnych. Ze względu na funkcję produkcyjną i zastraszania obóz nie może być ani zbytnio oddalony, ani ukryty, a jednocześnie, chcąc totalizować przestrzeń społeczną, musi ograniczyć przepływy informacji, dóbr oraz ludzi. Ten sam problem przekłada się na kwestię widzialności. Chcąc sprawować doskonałą kontrolę, nadzorcy dążą do panoptyczności, montują reflektory, transparentne ogrodzenie z drutu 
kolczastego i górujące nad polami wieże strażnicze. Działanie to sprawia jednak, że obóz staje się także w pewnym stopniu widoczny dla samych więźniów, jak i dla ludzi z zewnątrz. Nie bez powodu zatem, aby tę egalitarność widoczności minimalizować, zabrania się wychodzenia z baraków, obozy sytuuje się $\mathrm{w}$ pewnym oddaleniu od zabudowań, częściowo izoluje się je przy pomocy stref bezpieczeństwa (Interessengebiet), instaluje nieopodal granicy lasu lub innej naturalnej bariery, jak na przykład Morza Bałtyckiego w przypadku Stutthofu. Nie dotyczy to obozów zagłady, które powstawały niemal w zupełnym ukryciu, często pośrodku lasu i w dużym oddaleniu od centrów - nie tylko terenów zurbanizowanych, ale całego systemu świata, „na dalekim wschodzie”, który mieści się niejako poza mapą i przestrzenią wyobraźni, na obrzeżach zachodniego imaginarium (Marszałek 1987; Wachsmann 2016).

\section{Uniwersum linii prostych}

Następny aspekt spacjalny dotyczy wewnętrznej przestrzeni obozu. Należy mówić o dwóch typach architektonicznych realizacji. Pierwszej, zdeterminowanej przez założenia przestrzenne poprzedniej instytucji totalnej, jak na przykład zakładu poprawczego, więzienia lub zamku, gdzie dominowały grube mury, kraty, niskie stropy i cele. Drugiej, od początku wytworzonej na potrzeby tej konkretnej instytucji, w której urządzenie odpowiada pełnionej funkcji. Naziści korzystają z tych pierwszych, jednakże mają one dłuższy rodowód i choć też przynależą do gatunku „,architektury przemocy i represji” (Sofsky 2016: 66), to wydają się dość archaiczne, nie w pełni nowoczesne, pozwalające praktykować nieadekwatne już modele kontroli i nieprzygotowane na represje o masowej skali i zasięgu. Nazistowskie obozy od 1936 są już planowanę na znacznie większą liczbę więźniów, jak pokazuje przykład Majdanka, nawet na kilkaset tysięcy osób. Na poziomie projektu i niejednej realizacji pojawiają się systemy quasi-miejskie, zorientowane na populację, z infrastrukturą drogową, wodociągowa, energetyczną, produkcyjną (warsztaty, hale fabryczne, gospodarstwa rolne), konsumpcyjną (kantyna), sanitarną (zbiorniki wody, ciepłownia, pralnia, lazaret, krematorium), towarzyską (dom publiczny, kasyno, kino) i karną (więzienie, miejsce straceń) (Sofsky 2016). Nowe instytucje totalne charakteryzuje zatem nie obraz grozy w stylu gotyckim (zamkniętości i samotności, mrocznych lochów i zamczysk), lecz przeciwnie - kolektywnej, transparentnej, otwartej i oświetlonej struktury, doskonałego odbicia ducha zrodzonego z rozumu instrumentalnego i odpowiadających mu technik zarządzania. Obóz nie przypomina jednak wizji aseptycznego świata późnej nowoczesności oglądanej w filmach Sci-Fi. Obozy są brudne, przeludnione, pełne chorób i błota, toteż przywołują bardziej obrazy rewolucji przemysłowej w Anglii niż świat przedstawiony u Lema czy Dicka. Jednocześnie, co ważne w odniesieniu do zupełnie nowych realizacji, ich konstrukcja wychodzi od planu i mapy. Służą one kontroli przestrzeni poprzez naniesienie siatki punktów i linii, abstrakcyjnego systemu, który przekształca i wytwarza miejsca na podobieństwo mapy (Czapliński 2016).

Jak wygląda zatem przestrzeń wykreowana specjalnie dla obozu? Można zacząć od najogólniejszego planu rozlokowania lagru i dwóch konkurencyjnych koncepcji - systemu na bazie trójkąta lub prostokąta. Ten pierwszy pochodził z obozu Sachsenhausen w Oranienburgu pod Berlinem, drugi natomiast z miejsca „wzorcowego", a więc z Dachau, pod Monachium. Z przyczyn pragmatycznych wygrała koncepcja prostokątna, gdyż przestrzeń taką łatwo się dzieliło, kontrolowało i w pełni wykorzy- 
stywało. W ten sposób spełniała się doskonale zasada przejrzystości i zagęszczenia. Ponadto, i to chyba najważniejsze, obóz stawał się urządzeniem podatnym na zmiany, gdyż jego rozbudowa nie stanowiła problemu. Do istniejącego prostokąta dodawało się następny podobny moduł i kolejny; rozciągano dalej drut, dokładano wieże i wydłużano drogi, tworząc system rastrowy, infrastrukturalną siatkę na wzór amerykańskich miast, nie tracąc przy tym nic z pierwotnej funkcjonalności. Należy dodać, że dotyczyło to nowego typu obozów, w których dokładane pola zostały zaprojektowane tak, że odznaczały się względną autonomią i nie musiały mieć stałych połączeń z resztą więźniarskiej części, co chroniło zarazem w przypadku awarii danego elementu przed paraliżem całości i efektem domina. Najpełniej spełnił się ten wzorzec w Auschwitz-Birkenau, gdzie pole więźniarskie przedzielała najpierw na pół ulica, a następnie prostopadłe dróżki, odcinające kolejne bloki mieszkalne. Przestrzeń obozów organizowała zasada seryjności, sygnująca każdy obiekt, pole, blok czy łóżko numerem, przypisująca im te same typy ruchomości i kategoryzowaną odpowiednio „masę ludzką”, co odnosiło się także do Majdanka (Bauman 2009; Sofsky 2016). „Kartoteka tzw. duża - imienna, obejmowała karty zawierające dane personalne więźniów, numer obozowy, informacje, na którym polu i w którym bloku więzień przebywa” (Mencel 1991: 67). „Łóżka są numerowane, muszę każdemu z mojej sekcji wyznaczyć miejsce i wręczyć blokowemu spis łóżek" (Kwiatkowski 1966: 19). Zasada serii dotyczyła sposobu organizacji rzeczy w magazynach oraz więźniów, których numery przypisywano nie tylko do konkretnej lokalizacji w przestrzeni, ale i do obozowego czasu. Numer miał zawieszać przeszłość spoza instytucji totalnej i rozpoczynać zarazem historię jej trwania. Poszczególne serie więźniów oznaczano cyframi i symbolami, które stanowiły informację o momen- cie ich przybycia, typie transportu i statusie. Z perspektywy władzy seria była najlepszym z dostępnych narzędzi, które $z$ jednej strony segregowało i homogenizowało przestrzeń, materialność i ludzi poprzez wspólny kod, z drugiej natomiast, niby adres, pozwalało lokalizować poszukiwane „obiekty”.

Logika generująca i sygnująca przestrzeń w opisywany sposób zderzała się boleśnie z rzeczywistością. Ilustruje to dobitnie sprzeczny z nią pierwszy plan Majdanka z 7 października 1941 roku, który dotyczył części więźniarskiej. Miała się ona składać z dziesięciu pól - pięciu regularnych prostokątów, ale i pięciu trapezów o odmiennej powierzchni. Figura trapezu wynikała z próby dostosowania projektu do zachodniej granicy terenu, która biegła ukośnie. Wzdłuż każdej z dłuższych krawędzi tych geometrycznych figur miał stać jeden rząd baraków, wzdłuż krótszych krawędzi ulokowano infrastrukturę sanitarną oraz kuchnię, zaś środek pola przeznaczono na plac apelowy. Całość miała okalać podwójna linia drutu kolczastego i dwadzieścia pięć wież strażniczych. Plan lokacji oparty o figurę trapezu wynikał z potrzeby zagospodarowania całości terenów, aczkolwiek kłócił się z wymogiem serii, homogeniczności, a także zanadto zbliżał życie obozu do jego granicy. Korektę naniesiono na kolejnym planie, w którym zrezygnowano z pięciu trapezowych pól, a w ich miejscu usytuowano między innymi magazyny oraz pas ziemi ochronnej, gdzie znalazła się także psiarnia oraz strzelnica, znaki antycypowanego niebezpieczeństwa i przemocy, a tym samym symboliczna i złowroga granica. Zabieg ten miał sprawić, że sprawy lagru oddalą się zarówno z pola widzenia, jak i zainteresowania pobliskich mieszkańców osiedla²

${ }^{2}$ Za pomoc oraz udostępnienie materiałów dziękuję dyrektorowi Państwowego Muzeum na Majdanku Tomaszowi Kranzowi, Łukaszowi Myszale oraz Krzysztofowi A. Tarkowskiemu. 
Rys. 1. Plan budowy obozu jenieckiego dla 50 tysięcy osób, 7 X 1941.

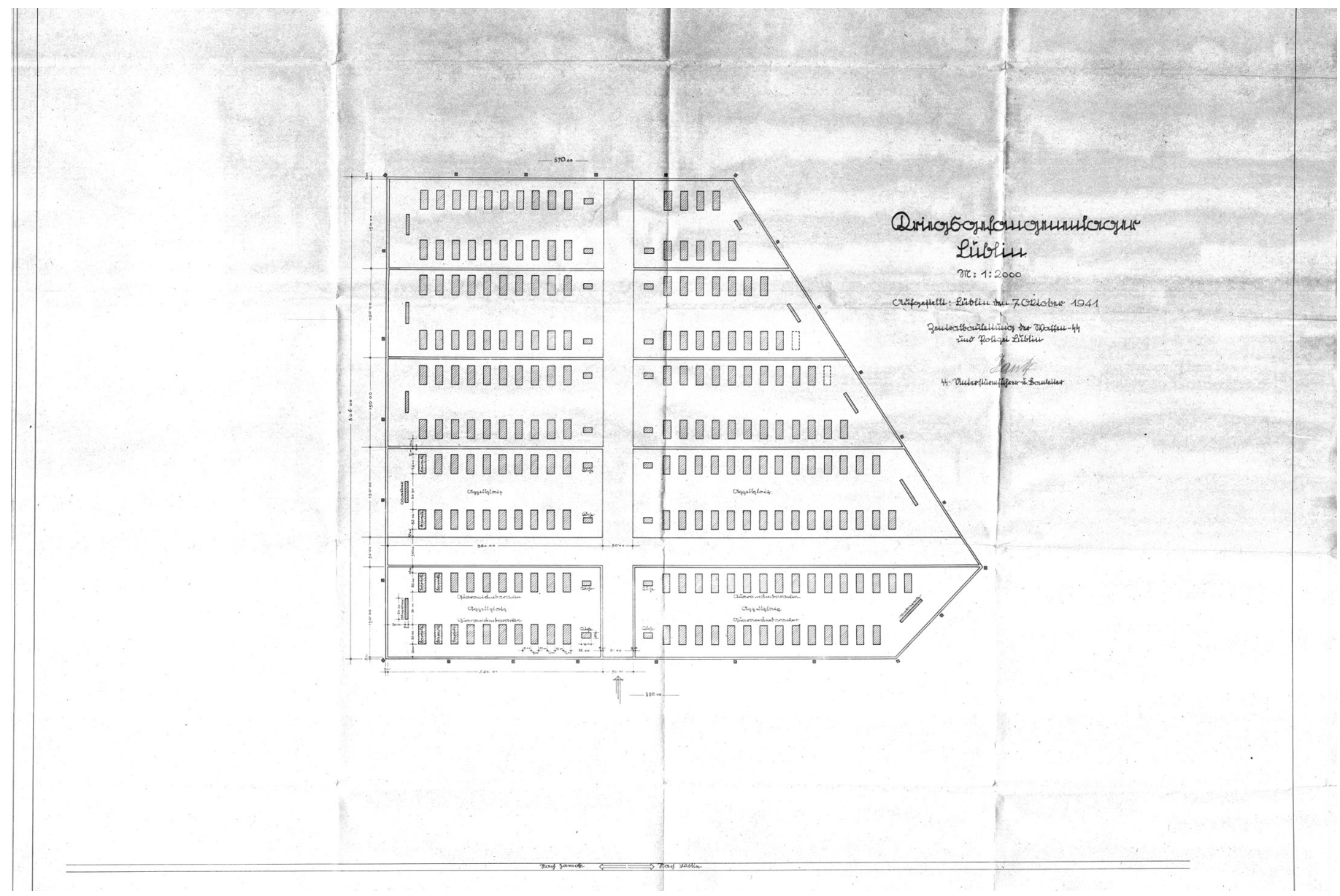

Źródło: Państwowe Muzeum na Majdanku.

Podobnie jak w przypadku innych obozów, pierwsze prace budowlane na Majdanku odbyły się rękoma więźniów i dzięki siatce instytucji totalnych. Chociaż część istniejącej zabudowy zachowano, to zajęto się wyrównywaniem terenu. Najpierw prace wykonywali polscy jeńcy pochodzenia żydowskiego, przyprowadzani codziennie z obozu pracy przy ulicy Lipowej w Lublinie. Tego samego miesiąca dołączyły do nich dwa tysiące jeńców radzieckich. Spali pod gołym niebem, najprawdopodobniej otoczeni siatką drutu kolczastego, co było praktyką stosowaną od I wojny światowej wobec jeńców, protostrukturą więzienną nowego typu upowszechnioną na masową skalę w kolejnej wojnie światowej. Po miesiącu prac teren był ogrodzony, ukończono pierwsze jego pole i pracowano nad następnym. Warto dodać, że w międzyczasie zaczął powstawać nowy plan rozbudowy kompleksu, który zaakceptowano do realizacji 23 marca 1942. Teren obozu miał teraz powiększyć się ponad ośmiokrotnie, zajmować powierzchnię 516 ha i składać z trzech części więźniarskich dla około 250 tysięcy osób - obozu jenieckiego, jego rozszerzenia (obozu koncentracyjnego) oraz zakładów odzieżowych (Krell 2002; Netz 2009; Sofsky 2016; Wachsmann 2016). 
Rys. 2. Plan generalny budowy obozu na Majdanku, 23 III 1942.

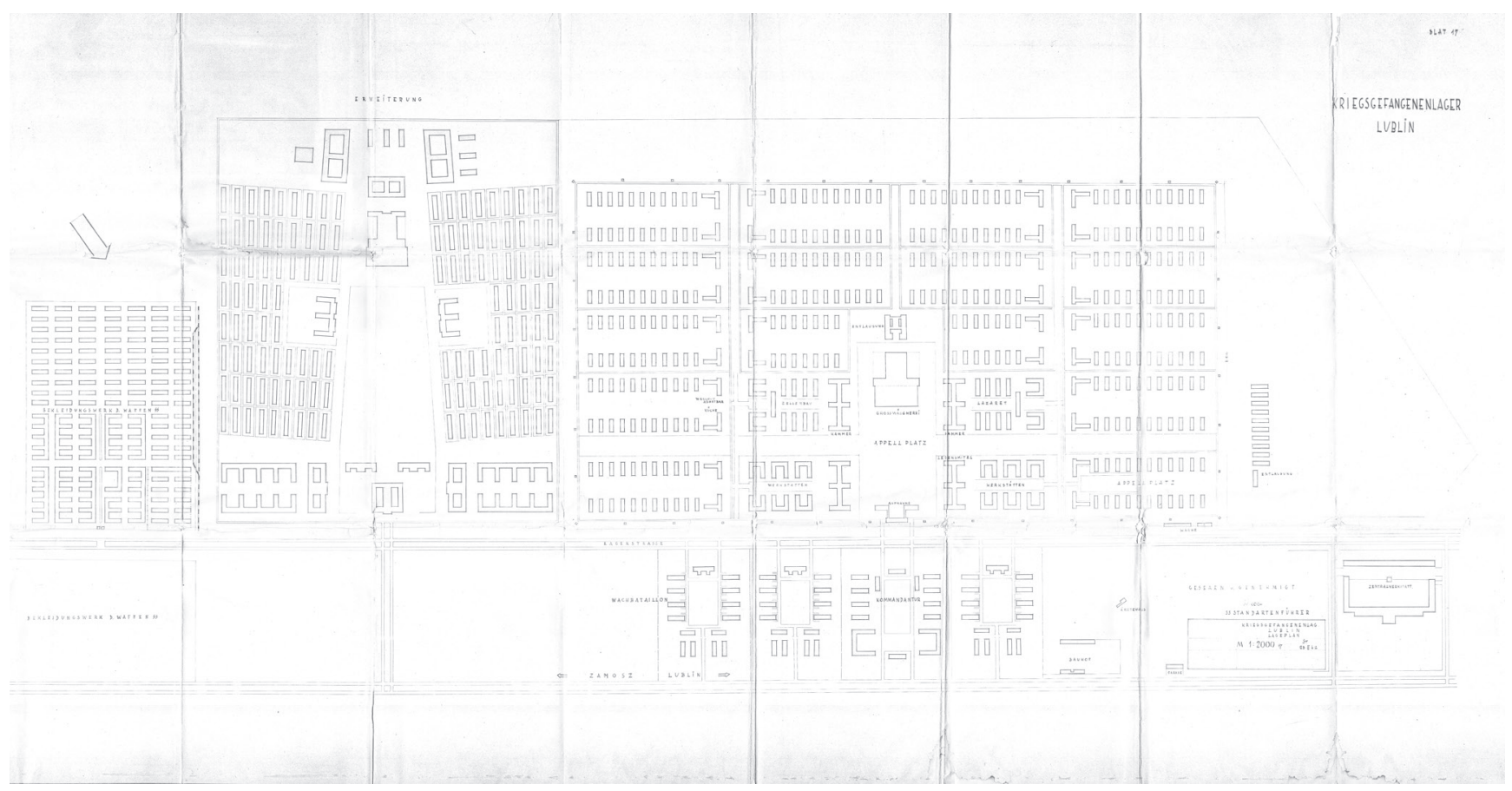

Źródło: Państwowe Muzeum na Majdanku.

Rys. 3. Plan sytuacyjny obozu koncentracyjnego na Majdanku.

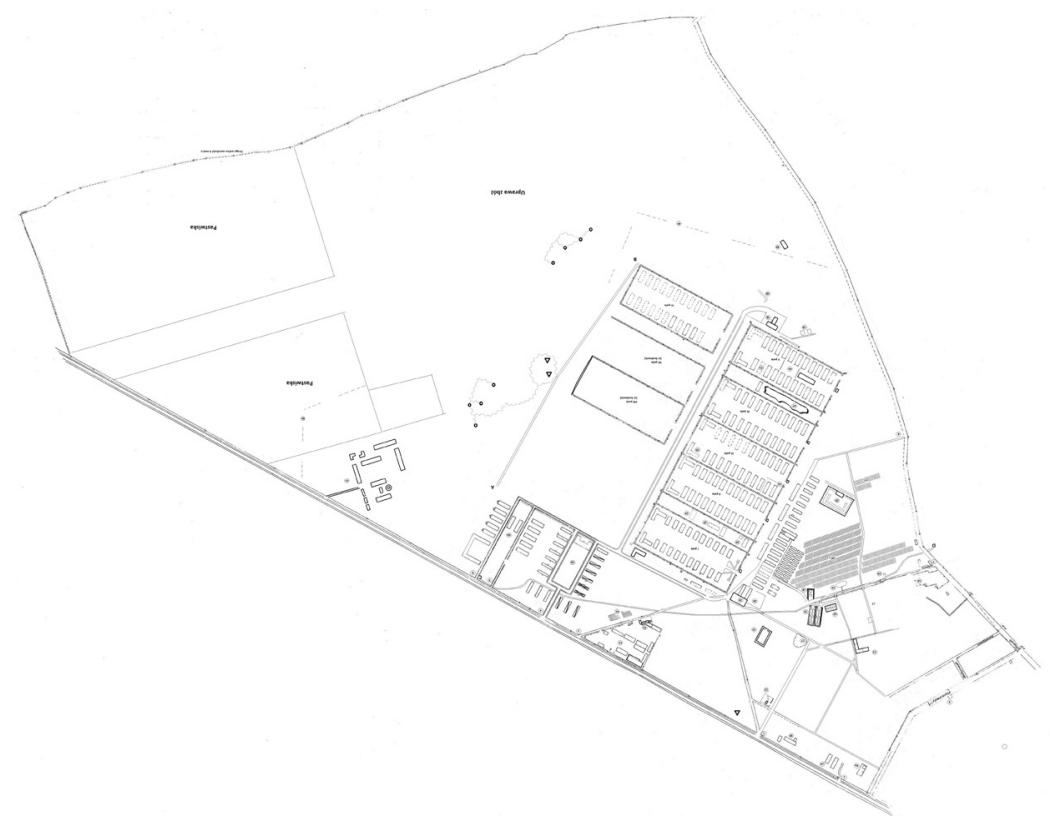

Źródto: Państwowe Muzeum na Majdanku, aut. Krzysztof A. Tarkowski. 
W maju 1942 roku zaakceptowano plan budowy ośmiu pól pierwszej części więźniarskiej, a dalsze prace postanowiono na czas wojny odłożyć. W rezultacie problemów aprowizacyjnych i konfliktów między administracją cywilną a SS zrealizowano ten plan tylko w części, budując niecałe sześć pól (Marszałek 1987). W okresie funkcjonowania obozu wybudowano w jego obrębie 280 obiektów, z czego trzy komory gazowe oraz dwa krematoria. Powierzchnia terenu okazała się mniejsza niż planowano, zajmując ostatecznie 270 ha i dzieląc się na trzy sektory: więźniarski, gospodarczy i administracyjny lub, jak sugeruje Sofsky (2016), dwie zony: mieszkalne (więźniów i strażników) oraz pracy (więźniów, strażników i pracowników administracji).

Drogi wewnętrzne miały ponad $4 \mathrm{~km}$ długości, a podwójna linia drutu kolczastego miała długość 5,6 km. Między ogrodzeniami oraz $\mathrm{w}$ pięciometrowym pasie pomiędzy linią wewnętrzną a barakami, tak zwanym pasie śmierci, rozsypano biały tłuczeń, który ułatwiał dostrzeżenie ludzkiej sylwetki, także w nocy, gdyż rzucała ona na biały materiał czarny cień. Wejście w strefę równało się ryzyku zastrzelenia, a dotknięcie drutu kolczastego pod napięciem - śmiertelnemu porażeniu, co komunikowały tablice w trzech językach - niemieckim, polskim i rosyjskim. Widoczność poprawiała dodatkowo infrastruktura - 130 punktów świetlnych na ogrodzeniach każdego z pięciu pól, osiemnaście wież strażniczych o wysokości 8,8 metra oraz zamontowane na nich ruchome reflektory. Oświetlone zostały także drogi, ścieżki, obiekty gospodarcze i administracyjne (Mencel 1991; Olesiuk 2011).

\section{Geometryczny porządek przestrzeni i społeczna asymetria pozycji}

Zacznijmy od konstatacji, że obóz więźniarski jest układem horyzontalnym, spłaszczonym. Rozszerza się i rośnie wyłącznie na boki dokładanymi polami i biegnącymi poziomo liniami drutu kolczastego. Z tego powodu ogromnego znaczenia nabierają obiekty korzystające z osi wertykalnej. Wyznaczają ją trzy strukturalnie powiązane punkty, a zarazem granice obozu - wieże strażnicze, brama oraz komin krematorium/szubienice. Stanowią one dominanty przestrzenne widoczne $\mathrm{z}$ wielu miejsc, które na każdym kroku przypominają o władzy i prawach lagru. Wieże tworzą kordon dookoła pól, kierują ruchem ciał, oślepiają światłem i grożą karabinem maszynowym. Przez swoją powtarzalność wzmagają poczucie osaczenia, ale także tracą na wyjątkowości jako wyróżniki przestrzenne, przesuwając akcenty na dwa kolejne elementy. Brama ma szczególne znaczenie, bowiem stanowi symboliczny pokaz siły, zapowiedź tego, co czeka osobę po jej przekroczeniu, a także wyznacza granicę społecznych światów. Choć na Majdanku było kilka bram na teren obozu i pól, to nie wyróżniały się zanadto, jak to miało miejsce w innych obozach. Wyjątek stanowi brama do kuchni na polu III o walorach artystycznych, bliższa ujęciu groteskowemu niż poważnej surowości bram znanych na przykład z Auschwitz I. Przedstawia ona świnię na ruszcie. Krótko o tej pracy pisze Pajączkowska (2017). Bramy były funkcjonalne, jedno- lub dwukondygnacyjne, ze skrzydłami lub stróżówkami po bokach, „łuki triumfalne władzy” były pozbawione ozdób. Jedynym estetycznie zabarwionym elementem były pojawiające się niekiedy napisy, wybite w surowej i prostej czcionce gotyckiej, jak "Czy ma rację, czy błądzi - to moja ojczyzna”, "Każdemu to, co mu się należy” czy „Praca czyni wolnym” (Sofsky 2016: 81-88; Pajączkowska 2017). Brama była miejscem ceremonii przyjmowania, rygoru i szykan, stąd nie powinno dziwić, że zapadała głęboko w pamięć. Podobnie było z krematoryjnym kominem, którego z bramą łączy dodatkowa zależność. Po przybyciu 
do obozu więźniów informują o niej strażnicy lub starsi stażem: „wypytujemy o warunki na Majdanku. Wszyscy mówią, że jedyne wyjście z obozu prowadzi przez komin" (Kwiatkowski 1966: 11).

Inicjacja do obozu ma miejsce przy jego wejściu, najczęściej w okolicach bramy, przez którą wchodzi się do obozu, stając się więźniem, ale już przez nią nie wychodzi. Komanda więźniów „przechodzą" przez bramy obozów, ale z niego nie wychodzą. Razem z pilnującymi ich strażnikami i psami przesuwają jego granicę, niosąc jego prawa oraz strukturę - przez strój, wygląd, zachowanie czy hierarchię. Nawet martwi i poza oficjalną granicą obozu mu podlegają - muszą wrócić na liczenie i kremację, bowiem nawet po śmierci jedyna droga wyjścia prowadzi przez komin. Zaznaczają to wyraźnie w swoich mowach esesmani i wiedzą, co mówią, ponieważ, wbrew słynnej frazie, nie jest znane uwolnienie $\mathrm{z}$ obozu za sumienną pracę (Sofsky 2016). Już w bramie, w obliczu doznawanej przemocy, więźniowie przeczuwają ironię i dysonans „mowy przywitalnej”, patosu gotyckiej czcionki czy zegara odmierzającego czas, które wskazują komin lub szubienicę jako jedyną drogę na wolność, bez względu na to, czy wykonuje się rozkazy i żyje zgodnie z regulaminem, czy też nie. Komin i szubienica są zatem wersją bramy prowadzącej nie tyle z wolności do więzienia, ile z życia do śmierci lub z porządku ziemskiego do pozaziemskiego. Można zatem powiedzieć, parafrazując Augustyńską maksymę, że jedynym więzieniem, jakie może opuścić więzień obozu, jest własne ciało. Nie należy ono wszakże do niego, gdyż zawsze musi wrócić na przynależne jemu miejsce w lagrze i zostać zewidencjonowane, bez względu na to, czy jest żywe, czy też martwe. Ciało więźnia pozbawione jego samego pozostaje w niewoli do momentu, gdy nie rozpocznie się proces utylizacji zwłok w popioły, gazy i pył. Proces prowadzący do „wyjścia” przez komin ma strukturę, prowadzi przez mniej lub bardziej formalne reguły i kroki, zaczynając od liczenia, poprzez stwierdzenie i odnotowanie zgonu, składowanie i przeszukiwanie zwłok, kremację oraz utylizację produktów ubocznych spalania. Tradycyjny rytuał przejścia związany ze śmiercią i pochówkiem zamieniony zostaje przez biurokratyczny antyrytuał, konsekwentnie redukujący człowieka do rzeczy i problemu technicznego związanego z zarządzaniem. Ciekawe pod tym względem wydaje się oddawanie rodzinom własności zarekwirowanej więźniom po ich śmierci. Są to ostatnie dowody ich istnienia $\mathrm{w}$ obozie, materialni świadkowie (Schuppli 2012) mogący przechowywać kształty ich ciał w ubraniach, masę i sposób chodzenia w butach, zapachy czy organiczne resztki, jak na przykład włosy.

Jednocześnie szubienica, jako symbol przypominający o śmierci, zdaje się mieć odmienne od komina znaczenie. Śmierć w komorze gazowej i spalenie ciała w krematorium jest anonimowe i dalekie. Śmierć na szubienicy przybiera znamiona spektaklu władzy, ma cechy ceremonialne - stojący na baczność więźniowie, obecność wysokich rangą funkcjonariuszy, gra dźwiękiem i ciszą (Posłuszna, Posłuszny 2015):

Wszystkich nas na III-cim polu ustawiono w czworobok wokół szubienicy stojącej w centrum pola. Odczytano wyrok. Za usiłowanie ucieczki, szubienica. Zbity i zmaltretowany, pogryziony przez psy, stał chwiejąc się, trzymając za rękę 10 letniego synka. Stojąc na baczność, musieliśmy mieć wzrok skierowany ku szubienicy. Dopilnowywali tego kapo, często używając pejczy. Wyrok wykonano. Mogliśmy powrócić do pracy, ale już na polu. Jedynie syn pozostał przy wiszącym ojcu. Tak biedak trwał przez dwie doby, dopóki zwłok nie przewieziono do krematorium. (APMM, VII/M-595: 8) 
Nieudane ucieczki najczęściej kończył „spektakl karania". Holenderski badacz Spierenburg zwraca uwagę, że już u początków nowoczesności szafot pełnił nie tyle tylko funkcję kary, ale - co równie istotne - spektaklu. Sam przebieg egzekucji od końca XVI wieku był już jednak mocno zrytualizowany i tracił z czasem swoją teatralną oprawą, czego najlepszym dowodem stało się przeniesienie szubienicy lub gilotyny do więzienia (Spierenburg 1995; Foucault 2009). Wcześniejsza śmierć-kaźń jako „sztuka podtrzymywania życia w cierpieniu przez dzielenie go na "tysiąc śmierci»" (Foucault 2009: 34) ustępuje miejsca nowej logice sprawowania władzy związanej z anulowaniem bólu. Egzekucja dotyczy odtąd nie umęczania ciała i odwlekania śmierci, ale samego życia i zredukowania go do kary ostatecznej. Taką funkcję ma pełnić w obozie komora gazowa. W Holandii wyroki miały ceremonialny charakter. Sędzia przybywał osobiście, aby oznajmić wymiar kary. Podczas wykonywania wyroku śmierci obecni byli włodarze miasta, a także prokuratorzy i sędziowie ubrani $\mathrm{w}$ ceremonialne płaszcze. Sekundowali im także przedstawiciele duchowieństwa, którzy razem z oskarżonym, a czasami również tłumem gapiów, odmawiali modlitwę. W wielu europejskich miastach, Paryżu, Sevilli czy Londynie, oskarżonych prowadzono najpierw demonstracyjnie przez ulice, a marszowi temu towarzyszyło bicie dzwonów. Podobnie czyniono w obozach, gdzie złapani więźniowie zmuszani byli niekiedy do uderzania łyżką o miskę, nieśli tabliczkę z jakimś szyderczym napisem lub jeszcze inaczej zwracali na siebie uwagę współwięźniów. W Amsterdamie zrezygnowano $\mathrm{z}$ wielu rozproszonych miejsc egzekucji i zastąpiono je tylko jednym, zlokalizowanym centralnie. Od oskarżonych oczekiwano okazania skruchy lub wdzięczności za wymierzoną karę (Spierenburg 1995; Foucault 2009). Zasygnalizowane elementy symboliczne wypływały $\mathrm{z}$ po- trzeby przysłonięcia nagiej przemocy, a zarazem podkreślenia mocy prawa oraz siły i majestatu władzy. W przypadku obozu koncentracyjnego śmierć na szubienicy również przyjmowała ceremonialny kształt, była eksponowana, a cierpienie - na dawny wzór - mnożone, ale zdaje się, że jedynie po to, aby zaprzeczyć możliwościom ucieczki i potwierdzić tym samym prawdziwość słów mowy powitalnejz obozu nie wychodzi się inaczej niż kominem, a za podważanie tej maksymy czeka cię „tysiąc śmierci”.

Genezą jednej z dominujących klisz wyobrażeniowych o obozie jako racjonalnej strukturze są zdjęcia lotnicze. Z powodu oddalenia zatraca się w nich detal, a wyostrza kontur. Ukazuje się obraz stworzony z linii prostych, które są osią dla rzędów baraków, wież strażniczych, dróg, siatki z drutu i przerw między polami (podkreślonych kontrastowym białym kamieniem). Spojrzenie to pozwala wyabstrahować z widoku człowieka i materię, a w zamian ujrzeć przejaw rozumu, geometrycznej precyzji i kojącej symetrii, które swoje źródło mają w abstrakcyjnej praktyce projektowania. Wyobrażenie to zdaje się zatem sprzyjać tezie o racjonalności i instrumentalności rozumu, ucieleśnionej w postaci obozu (Baumann 2009; Horkheimer; Adorno 2010). Obóz jest urządzeniem mobilnym, możliwym do wybudowania niemal w każdych warunkach, o ustalonych elementach, instrukcji, strukturze przestrzennej i otwartym na rozbudowę o kolejne komponenty. W tym sensie przypominać może meble Ikei czy klocki Lego wykorzystane w pracy Zbigniewa Libery (van Alphen 2004).

Przechodząc nieco niżej, na poziom wież strażniczych i człowieka, układ przestrzenny zaczyna przejawiać pewne niedoskonałości. Słupy ogrodzenia bywają odchylone, podobnie jak nierównomiernie rzucane snopy światła. Różnią się między sobą 
baraki, nie tylko kształtem i wielkościa, ale również układem okien i wejść. Druty tworzą raczej plątaninę i kłęby linii niż idealnie proste odcinki. Dlatego obóz jako przestrzeń widziana tylko z odpowiedniego kąta lub oddalenia odzwierciedla idealny porządek rozumu. Natomiast w dużym przybliżeniu pojawiają się na tym wyobrażeniu poważne rysy. Przestrzenne urządzenie obozu przejawia geometryczne uporządkowanie, stanowiące translację biurokratycznych podziałów i funkcji, które są z kolei sformalizowaną w formie instytucji ideologia, czyli systemem myśli. Jednak zarówno w obszarze myśli, jak i w ich materializacji w przestrzeni ujawniają się sprzeczności i wyjątki od reguł, co pokazuje między innymi przykład omawianych w dalszej części enklaw.

Faktura racjonalności jest zatem chropowata, przebijają przez nią afekty, niemniej wciąż stanowi ona dominujący modus organizujący przestrzeń. Geometryczność tej struktury rządzi się jednak logiką asymetrii, która stratyfikuje społeczność obozu również pod względem przestrzennym. Dotyczy to dwóch relacji: znanego $\mathrm{z}$ instytucji totalnych podziału strażnik-więzień i wewnętrznych różnic społeczności więźniarskiej.

W pierwszym przypadku przyjrzyjmy się granicy ich świata. Strażników otacza linia drutu kolczastego, posterunki przy bramach i mrok. Więźniów dwie linie drutu kolczastego pod napięciem, wieże strażnicze, psy, światła i strefa śmierci z białym kamieniem, które multiplikują widoczność człowieka. Addytywnie więźnia otacza jeszcze sfera lagru, czyli granica bezpieczeństwa SS. W obydwu sytuacjach asymetrię pozycji podkreślają również trzy główne typy baraków. Wszyscy mieszkają w barakach drewnianych, ale strażnicy mają budynki specjalnie ocieplone oraz inaczej podzielone wewnętrznie
(Mailander 2015). Analogiczne baraki cywilne dla więźniów są chłodniejsze i mniej prywatne, podczas gdy baraki stajenne są najzimniejsze i nagorzej oświetlone (APMM, VII/M-497; Kiełboń, Balawejder 2004). Zmiennymi różnicującymi są zatem ciepło/ izolacja, stłoczenie/prywatność oraz światło/widoczność. Niektóre baraki mają dwa wejścia, z których jedno dedykowane jest dla więźniów, drugie z kolei dla władz obozu oraz arystokracji obozowej (APMM, VII/M-688).

Pozycję więźniów w kontekście przestrzennym różnicuje to, co Goffman (2011) nazywa systemem oddziałów i przydziałów. Pierwszy dotyczy miejsca życia (spania i odpoczynku), drugi - pracy. Na system składają się: przestrzenie życiowe, jednostki administracyjne i sposoby wyjść i przepustek. Na przykład w analizowanym przez Goffmana szpitalu najniższy poziom w hierarchii oddziałów przedstawiały drewniane ławy, kiepskie jedzenie i miejsce do spania, najlepszy zaś własny pokój, przywilej spacerów, dobre kontakty z personelem czy lepsze jedzenie. Nagrodą była możliwość korzystania z przywilejów oddziałów i przydziałów, natomiast karę oznaczała ich utrata. Dane oddziały kreowały także odmienne przestrzenie, różnicujące zakresy swobód oraz działań w obrębie sekretnego życia instytucji. System nagród i kar był zatem zależny od przestrzeni, jej reguł i materialnej scenografii. W obozie o wyborze do systemów oddziałów i przydziałów decydował najczęściej system kategorii więźniów - do najgorszych prac kierowani byli Romowie, Żydzi i jeńcy Radzieccy, potem Polacy oraz inne "rasy słowiańskie”: „to blok mieszkalny. Tak, jak w «dziesiątce», są tam tylko Polki. Następne za nim dwa bloki (nr 20 i 19) - bloki mieszkalne Rosjanek. Potem «osiemnastka» - blok Żydówek" (APMM, VII/M-688:13). Podział przekłada się samorzutnie na warunki stłoczenia - w bloku pol- 
skim jest 320 osób, w rosyjskim dwukrotnie więcej, a w żydowskim - najwięcej (APMM, VII/M-688): „W blokach żydowskich na przestrzeni «zaplanowanej» obozowo dla około 200 kobiet mieszkało ich 700-800" (Błońska 1988: 152).

W różnych okresach, w zależności od polityki konkretnego obozu lub systemu obozów, trajektorie te ulegały zmianie. Istniała zawsze szansa, czy to przez przebiegłość, spryt i wiedzę, czy łut szczęścia, aby przekroczyć strukturalne ograniczenia kategorii, wykazać mobilność i zmienić pozycję w stratyfikacji, którą generował system oddziałów i przydziałów (Goffman 2011; Sofsky 2016). Za oddziały należy w tym przypadku uznawać pola i bloki, które różnicują warunki życia, rozumiane jako konglomerat czynników materialno-społecznych, takich jak rodzaj baraku, bliskość wież strażniczych, charakter załogi wartowniczej, grupa osadzonych. Odmienność pozycji wynikająca z przynależności do określonego oddziału wiąże się niekiedy bezpośrednio z przydziałem. I tak więźniowie-lekarze przebywają na rewirze, a mechanicy w oddzielnej części warsztatowej. Niektóre komanda pracy mają bloki dedykowane wykonywanej czynności, na przykład „pralnia” i „szycie”. Łączność pomiędzy pracą a blokiem przekłada się również na warunki i charakter panujące w jego wnętrzu. Przykładowo szpital, również jako typ instytucji totalnej, może być dodatkowo oddzielony granicą drutu, a przekroczenie jego progu wiąże się automatycznie ze zmianą stroju - więźniowie pacjenci oddają pasiaki i przywdziewają stroje rewirowe, a lekarze narzucają białe fartuchy i opaski z krzyżem (Perzanowska 1970). Podobna reguła dotyczy wydzielonego przestrzennie komanda samochodowego. Jego izolacja przestrzenna wywołuje ponadto przesunięcia w ramie materialnej, uzmysławiając hierarchizujący charakter praktyk z nią powiązanych:
Kapo baraku mieszkalnego przydzielił każdemu z nowych pryczę z siennikiem wypchanym słomą oraz po dwa koce, zaznaczając, że tutaj nie obowiązuje tak jak na innych blokach metoda ścielenia prycz pod linię i ostry kant. Stoły, które stały tu między rzędami prycz, i taborety służyły rzeczywistym potrzebom komanda podczas spożywania posiłków, nie były więc złudną makietą. Każdy z nowych dostał też kombinezon roboczy. (Panz 1977: 229)

Asymetria pozycji w instytucji totalnej dotyka również krajobrazu. Strażnicy łamią jego szary, nudny i seryjny charakter, personalizując pokoje, uciekają w zieleń lub na miejscu tworzą mikroogrody i sadzą kwiaty:

\section{Erna Walisch, świadek (b. dozorczyni):}

Nasze baraki stały bardziej na zewnątrz, nie były ogrodzone. Byłyśmy, że się tak wyrażę, na wolnym powietrzu.

Luzie Moschko, świadek (b. dozorczyni): Miałam tam pokój. Tutaj było moje łóżko, a tutaj na ścianie wisiał Himmler. (Fechner, Kranz 1996: 85)

Hildegard Lachert, oskarżona (b. dozorczyni): Gdy wracałyśmy do domu, to znaczy do naszych baraków, każda miała oddzielny pokój. Byłyśmy zmęczone i rozbite. Trzeba było coś napisać, uporządkować bieliznę. Miałyśmy rzeczywiście dosyć. Byłyśmy zadowolone, że mogłyśmy przez dziesięć minut być same, przeczytać książkę. Dzięki Bogu mogłam chodzić codziennie do majątku na Felinie. Tam jeździłyśmy codziennie konno przez lasy. Mieli czystej rasy Araby, są one trochę mniejsze od innych koni czystej rasy. Trzeba było na nich codziennie jeździć. Byli mi bardzo wdzięczni, że wzięłam jednego i jeździłam na nim.

Luzie Moschko, świadek (b. dozorczyni):

Mój pokój w Lublinie sprzątała żona polskiego oficera. Codziennie kładłam jej pięć papierosów i kawałek 
kiełbasy. Miałam całą skrzynkę brykietu, gdy wracałam do domu, w piecu palił się ogień. Ona tarła kartofle, wyciskała i zostawiała je. Wiedziała bowiem, że gotuję polskie kluski.

Emil Laurich, oskarżony (b. pisarz w kancelarii obozowej): Gdy jest Pan młody, to śmieje się do Pana cały świat. Ja mieszkałem poza obozem. Rano jechałem na służbę, byłem zadowolony, gdy wieczorem ją kończyłem.

Lilii Laurich, żona oskarżonego Emila Lauricha:

Mieliśmy piękne, miłe mieszkanie. Urządziliśmy je bardzo przyjemnie. Chodziliśmy do teatru, do kina, na spacery. (Fechner, Kranz 1996: 110)

.Więźniowie doznają wizualności pozbawionej przyjemnych doznań, znanych chociażby z wolności. Brakuje zieleni, podłoże latem jest suche i twarde, a w innych okresach błotniste i rozbite:

Na III polu nie ma żadnego drzewa ani krzaka. Jest kawałek murawy z kilkoma klombami przed pierwszym blokiem od ulicy, tj. blokiem 12, w którym mieści się izba chorych III pola. Poza tym twarda, goła ziemia, udeptana przez tysiące nóg i wyjeżdżona przez setki furgonów. (Kwiatkowski 1966: 23)

Podstawowym elementem krajobrazu więźniów, poza dominantami wertykalnymi, jest jednak przede wszystkim drut kolczasty. Znajdują się oni ciągle w jego sąsiedztwie, jest wyższy od nich, wyznacza im horyzont, a nawet skaża niebo (Netz 2009; Sofsky 2016). Gdy jadą w ciemnym wagonie do obozu, wąskie okienko przecinają linie drutu kolczastego, który blokuje ucieczkę. Dlatego już od tego momentu rozpoczyna się proces wzrokowego osadzania, budowanej aury osaczenia i bezsilności, co stanowi dodatkowy argument o nieoczywistym zasięgu obozu. Rytm codzienności wyznaczany przez apele oraz „odświętne” pokazy władzy zmusza wręcz do tego, aby przyglądać się narzędziom opresji, jak podczas bicia i chłostania.

Przemoc i gwałt symbolizują zatem także porządek wizualny, przesączając się okiem do głębin podświadomości w rytmie dnia codziennego. Filtr ten nie tyle nie dopuszcza alternatywnych obrazów, co przede wszystkim sposobów patrzenia, które nasycają wizualność synonimiczną aurą trwogi i pesymizmu, czyniąc je w ten sposób podobnymi do siebie nawzajem (Krajewski 2011). Osadzanie dotyczy note bene również strażników, tyle że, po pierwsze, drut znaczy dla nich coś innego, gdyż ma odmienną funkcję - ochronną. Po drugie, w doświadczeniu codziennym dzieli ich od niego duża odległość, patrzą na niego z góry. Stąd przecina krajobraz na niższej wysokości. Ten rytm wizualności przekłada się na obozową ikonografię, dla której drut stanowi nieodłączny element budowanego obrazu przemocy.

\section{Ekologia organizacji totalnej}

Gdyby zdefiniować obóz jako twór przestrzenny, warto byłoby zacząć od wytyczenia jego granic. Uważam, że rozciagają się one daleko poza linie na mapach wyznaczonych przez architektów i administrację, gdyż obóz funkcjonalnie powiązany jest z sieciami podobnych sobie instytucji - zarówno innych lagrów, jak i instytucji totalnych, na przykład więzień (Posłuszny 2017a). Jednakże w przypadku konkretnych obozów koncentracyjnych możliwe staje się precyzyjne określenie ich formalnych ram. Zewnętrzna granica terenu podległego obozom nie była zazwyczaj skonstruowana z materialnych barier, które uniemożliwiały ruch i stanowiły wyraźną przeszkodę, jak na przykład ogrodzenie. Istniały za to wskaźniki granicy jak tablice informacyjne o groźbie śmierci, posterunki, patrole strażników, a niekie- 
dy nawet wkopywane w ziemię miny. W ten sposób staje się jasne, że chociaż granice obozów były geodezyjnie określone, to praktyki władz i strażników mogły do pewnego stopnia manipulować ich zasięgiem. Czy komando więźniów, które wyruszyło do pracy pod eskortą esesmanów, opuszczało obóz? Czy na parę godzin uwalniali się od niego, czy raczej obóz ciągnął się za nimi za sprawą łańcucha strażników? To samo pytanie można z powodzeniem odnieść do innych miejsc pracy, czasami oficjalnie przekształcanych w zależne podobozy czy miejsca kaźni, gdzie mordowano lub pozbywano się zwłok więźniów (Marszałek 1987; Mencel 1991). Trwałość relacji z tymi przestrzeniami wskazuje na silnie związanie i zależność, a jednak formalnie nie są to miejsca włączone i podległe obozowi. W tym ujęciu proponowałbym pomyślenie o obozie, inspirując się koncepcją ekologiczną szkoły chicagowskiej i podzieleniem „organizmu” lagru na kręgi - podobozie, obóz z dwoma częściami - SS i więźniarskimi - oraz enklawy.

\section{Rys. 4. Schemat ekologiczny obozu koncentracyjnego.}

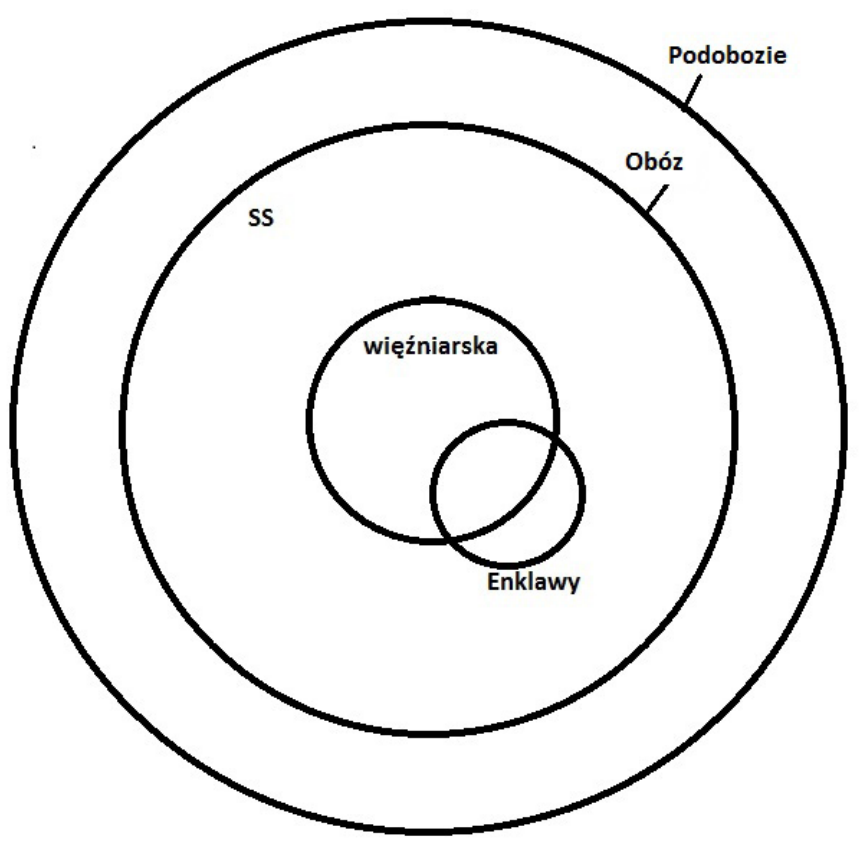

Źródło: opracowanie własne.
Najdalszy z nich obejmowałby podobozie, tereny nieopodal obozowe, które choć formalnie nie przynależą jego jurysdykcji, to jednak są z nim w różnorodny sposób powiązane, każąc myśleć o nich w kategorii jego części. Kolejnym kręgiem byłby formalnie wyznaczony obszar obozu. W przypadku Majdanka jest on prostszy do wskazania, gdyż odcina go od krajobrazu około trzymetrowa linia drutu kolczastego, oddalona od drogi o sześć metrów z wbitymi tablicami ostrzegającymi co $50 \mathrm{~m}$, że przekraczanie i fotografowanie grozi śmiercią (Sofsky 2016: 67-68). Drut stanowi główny element organizujący przestrzeń obozu i podkreślający status wykrajanych obszarów. Drut okalający obóz SS jest pojedynczy i niezelektryfikowany, podczas gdy część więźniarską otacza podwójna linia drutu pod napięciem. Na pozór przypomina ten sam obiekt, $\mathrm{w}$ obydwu sensach wiążąc się $\mathrm{z}$ ograniczeniami mobilności, a mimo to pełni odwrotne role. Jak zauważa Netz (2009), zamknięty krąg, do którego nie można dostać się z zewnątrz, definiuje własność, której granica chroni przed intruzami z zewnętrz. W drugą stronę, gdy uniemożliwiamy mobilność na zewnątrz, przestrzeń tę nazywamy więzieniem, a ochronie podlega nie to, co znajduje się wewnątrz, lecz po drugiej stronie kręgu. Członkowie SS mieli niemal nieograniczoną wolność poruszania się po terenie obozu. Drut dookoła dużego obozu pełnił raczej funkcje ochronne niż więzienne, o czym świadczy brak świateł oraz wież strażniczych w jego sąsiedztwie, jak również usytuowanie bunkrów na wschodniej granicy lagru. Grupa, przeciwko której mógł być skierowany drut, byliby strażnicy z koszar, którzy mieszkali na miejscu i byli ograniczani w poruszaniu się poprzez system przepustek. Jednak właśnie ta przepuszczalność podkreśla różnice w przynależności do różnych instytucji totalnych $\mathrm{w}$ jednej przestrzeni, pomimo zajmowania analogicznych pozycji w ich obrębie. Z punktu widzenia 
założeń teorii instytucji totalnych strażnicy, podobnie jak więźniowie, są mieszkańcami („,pensjonariuszami") instytucji totalnej - ci pierwsi obozu, drudzy koszar (por. Baranowska 2013). Dla więźniów strukturalnym przeciwieństwem są właśnie strażnicy, dla strażników z kolei personelem jest kadra oficerska. Strażnicy zatem, w zależności od kontekstu instytucjonalnego, zajmują zarówno pozycję „pensjonariusza”, jak i „personelu”. Pozycję tę podkreśla chociażby przestrzenny podział na baraki żołnierskie, podoficerskie i oficerskie na Majdanku.

Mobilność więźniów jest z kolei ograniczona w trójnasób. Po pierwsze, za sprawą ogrodzenia części więźniarskiej. Po drugie, ze względu na podzielenie tej przestrzeni na samodzielne pola, które nie mają bezpośrednich połączeń, ale droga do nich wiedzie przez dużą część obozu. Sofsky i Netz mówią o nich jako o obozach w obozach, ponieważ odznaczają się autonomicznością i oddzielają przestrzennie odmienne kategorie więźniów, na przykład kobiety, Żydów, zakładników, jeńców, więźniów politycznych. Ponadto na Majdanku każde pole, poza barakami mieszkalnymi, ma także latryny, kantynę, rewir chorych, plac apelowy, a na środku pola szubienicę (Marszałek 1987). Oznacza to, że więźniowie nie tylko mieszkają i śpią w przypisanej im przestrzeni, ale również żyją w niej, spędzają czas i nawiązują kontakty społeczne. Odizolowanie przestrzenne wpływa zatem na homogenizację, którą wzmacnia dodatkowo profilowanie grup oraz podział na polach według określonego klucza. Są to czynniki niewątpliwie totalizujące instytucję, tym bardziej, jeśli przypomnieć o zonach pracy, które choć mniej hermetyczne, to wciąż mieszczą się w obrębie terenu SS lub są jego organizacyjnym przedłużeniu podoboziem. Po trzecie, przez zakazy opuszczania baraku w nocy lub w sytuacjach określonych przez władze obozu, jak mordowanie lub kremacja zwłok.
Wariacją trzeciego ograniczenia jest skierowanie osoby do rewiru, bloku umierających lub więzienia, których również nie wolno opuszczać bez zezwolenia. Istnienie więzienia w obozie, jak w przypadku Auschwitz I, uzmysławia gradację obozowej przemocy poprzez ograniczenie mobilności do minimum, na przykład poprzez osadzenie w stojącym bunkrze. Warto ponadto podkreślić, że strażnicy mogą nie tylko zaglądać, ale również wchodzić na pola więźniarskie, co rozszerza ich przestrzeń mobilności kosztem więźniów, którzy unikają służby SS, umykając przed potencjalnym niebezpieczeństwem. Granica wpływu SS rezonuje zatem na zewnątrz obozu, ale i do jego centrum, podczas gdy przestrzeń bezpieczeństwa więźniów zostaje ograniczona do zera.

Idąc śladem drutu, zauważamy, że w przestrzeni obozu znajdują się jeszcze miejsca dodatkowo odizolowane, i to zarówno w części SS, jak i więźniarskiej, które nazywam enklawami. Dla SS będzie to skład budowlany, dom komendanta czy psiarnia, podczas gdy dla więźniów niektóre bloki Żydówek, kwarantanna, szpital obozowy (rewir), blok Sonderkommando czy warsztat samochodowy (Panz 1977; Mencel 1991; Netz 2009; Sofsky 2016). Przekraczanie granic tych miejsc wymaga specjalnych uprawnień, a dla więźniów niekiedy droga wiedzie tylko w jednym kierunku. Miejsca te stanowią czasami enklawy instytucjonalne, takie jak więzienie dla zakładników, pole jeńców wojennych czy robotników przymusowych Wehrmachtu, a ich odmienna instytucjonalna przynależność nie zawsze jest artykułowana przestrzenno-materialnie poprzez odseparowanie drutem. Nie jest to jednak jurysdykcja obozowego SS, dlatego mogą obowiązywać tu alternatywne regulaminy. Inne enklawy podlegają kierownictwu obozu, ale tworzą jakoby nową organizację totalną w instytucji totalnej. Jest to szczególnie 
widoczne w przypadku szpitali obozowych oraz więzień/kompani karnych, które nierzadko oddziela drut lub inna bariera, a dodatkowo ich więźniów różnicuje niekiedy strój lub jego oznaczenia.

Jeśli centralną figurą obozu jest muzułman, to jego kluczem przestrzennym, niejako jądrem ciemności nie jest wcale, moim zdaniem, krematorium i komora gazowa, umieszczane najczęściej na uboczu, poza częścią więźniarską - na Majdanku najpierw na I międzypolu, a później za polem $\mathrm{V}$, natomiast w Birkenau za polami więźniarskimi. Byłoby nim raczej miejsce, gdzie trafiają osoby bliskie śmierci, stojące na granicy światów, chore i muzułmanie (Domańska 2010). To przestrzeń pusta i nicująca, którą omijają strażnicy w strachu przed zarażeniem i z tego samego powodu niechętnie zaglądają tam też inni więźniowie. Byłaby to przestrzeń odpadów, śmietnikowa i nieokiełznana antyprzestrzeń systemu, który generuje żywe trupy, przeciwludzi, zamieszkana przez człowiecze cienie, uporczywie trwające przy życiu, chociaż już w nim nie uczestniczące. Ponieważ obóz trawi więźniów, a opisywana przeze mnie przestrzeń i przynależna jej społeczna kategoria stanowią koniec jego przewodu pokarmowego, to nacechowane zostają jako odrażające i nieczyste (Douglas 2007). Dopiero uśmiercenie, proces przekształcenia zwłok oraz ich utylizacji dokonywany w komorach gazowych i krematoriach przez SS i Sonderkommando, kończy ten cykl.

Dodajmy, że obóz koncentracyjny od obozu zagłady odróżnia funkcja pracy. Treblinka czy Bełżec produkują tylko unicestwienie, dlatego słusznie nazywane są fabrykami śmierci. Obozy koncentracyjne również znamionują się bardzo wysoką śmiertelnością, ale o wiele mniejszą i zapośredniczoną przez pracę, stąd można by je określić jako śmiercionośne fabryki. Z tego samego powodu w ich sercu stoi mu- zułman i przestrzeń tabu, której unikają wszyscy członkowie instytucji totalnej. Analogicznie centrum wyrażającym sens fabryk śmierci będzie komora gazowa i krematorium oraz przynależne im Sonderkommando.

\section{Zakończenie}

Nazistowska maszyneria składała się z około sześćdziesięciu obozów koncentracyjnych, a w okresie II wojny światowej $\mathrm{z}$ dwudziestu kilku, z ponad tysiącem podobozów. Jeśli dodać obozy pracy, obozy jenieckie czy getta, to otrzymujemy liczbę około czterdziestu tysięcy miejsc, choć i to nie jest pełna lista, jeżeli wziąć pod uwagę inne instytucje totalne składające się na nazistowski system (Megargee 2009). Kilkadziesiąt tysięcy miejsc, przez które przechodzi kilkanaście milionów ludzi jako więźniowie instytucji. Ograbianie z przestrzeni jest stopniowe, ale jako funkcja sytemu uwidacznia się z całą siłą z chwilą zakładania miejsc odosobnienia - więzień, gett i obozów koncentracyjnych. Nieprzypadkowo losy więźniów przecinają się w podobnych punktach, wiążą z analogicznymi miejscami i posuwają po tych samych torach. Dotyczy to między innymi związania z instytucjami totalnymi, w których obóz koncentracyjny stanowi jedną z wielu organizacji, ale prawie zawsze poprzedza ją inna instytucja totalna obóz przejściowy, jeniecki, więzienie czy getto.

Myślenie w kategorii sieci uprawomocniają analizy historyczne, które wskazują na przechodniość funkcji i przestrzeni pomiędzy instytucjami totalnymi, na przykład domy pracy i statki przekształcały się w więzienia, przytułki i domy poprawcze, a klasztory działały jako areszty, więzienia dla mnichów, szkoły z internatem czy różnego rodzaju domy opieki. Jest to o tyle ważne, że podkreśla rolę aranżacji przestrzeni i materialności dla wielu odmiennych 
typów instytucji totalnych. Różnorodność tę podkreśla przypadek wielu obozów, w tym Majdanka, w którego przestrzeni funkcjonowały najpierw obóz jeniecki, później koncentracyjny i zagłady, a na końcu obóz NKWD. Co więcej, na Majdanku (KL Lublin) znajdowały się autonomiczne komórki organizacyjnie, jak lazaret dla radzieckich jeńców podległy Gestapo, obóz przejściowy dla zakładników, zależny od Policji porządkowej, oraz obóz pracy Wehrmachtu przynależny Głównej Komendzie Polowej w Lublinie (Marszałek 1987; Sofsky 2016). Widać zatem wyraźnie, że jedna przestrzeń, zaaranżowana według zasady serii, jest miejscem egzystowania różnych form instytucji totalnych zarówno synchronicznie, jak i diachronicznie. Uwaga o przekładalności przestrzeni między różnymi organizmami politycznymi nie ma charakteru piętnującego, ale służy ukazaniu, że instytucje totalne są trwałe i nie zależą wyłącznie od kontekstu politycznego. Uzmysławia to z jednej strony fałszywość wizji jednorodności instytucji totalnych, z drugiej zaś silny związek miejsca i jego przestrzeni z wieloma emanacjami władzy, które różnią szczegółowe zadania, organizacyjna przynależność, zasięg czy specyfika grupy, wobec której działają. Łączy natomiast funkcja ustanawiania i reprodukowania porządku, w których przestrzeń i materialność odgrywają kluczową rolę.

Przestrzeń obozu zbudowana jest w oparciu o oś horyzontalną, składa się z niskich budowli na dużej przestrzeni, dlatego symbolicznej wagi nabierają dominanty wertykalne - komin, szafot oraz brama. Inicjacja odbywa się w okolicach bramy, a wzrok ciągle napotyka na komin i szubienicę, materializujące groźbę śmierci. Nikt i nic, co przechodzi przez bramę obozu nie może przez nią wyjść takie samo i dotyczy to zarówno ludzi, jak i przedmiotów. Przestrzeń obozu jest parcelowana przy pomocy drutu kolczastego, a każda parcela ma swoje funkcje.
Obóz składa się z części gospodarczych (rolnictwo, budownictwo, wytwórstwo), więźniarskiej oraz administracyjnej (m.in. koszary). Część więźniarska i strażnicza są funkcjonalnie niezależne - każda posiada własną infrastrukturę mieszkalną, higieniczną, kuchenną i inne. Obóz więźniarski ma kształt prostokątny jako całość, a jego części stanowią mniejsze, niezależne prostokąty nazywane polami. Wyłączenie jednego pola nie oznacza zatem dysfunkcjonalności całego obozu. Ponadto wykorzystanie struktury parceli, niezależnych prostokątów, wykrajanych i oddzielanych drutem kolczastym, umożliwia dokładanie do siebie kolejnych elementów strukturalnych, bez konieczności przebudowy całej struktury. Dane typy instytucji totalnych uobecniają się także w obozie, a ich odmienność podkreślają granice kreowane przez drut kolczasty, który dodatkowo okala takie miejsca jak: szpitale, więzienia, krematorium czy obozy jenieckie. Izolacyjność wytwarzana przez granice obozu SS jest wzmacniana granicami między polami, co wpływa na ograniczenie interakcji w relacji do świata zewnętrznego oraz wewnętrznego. Na Majdanku usiłuje oddzielać się także kategorie więźniów poprzez przyporządkowywanie ich do odmiennych pól i baraków. W jednej przestrzeni wytwarza się miejsca dla wielu kategorii społecznych (jeńców, więźniów politycznych, zakładników, pracowników), którymi równie dobrze mogłyby się zajmować odpowiednie instytucje totalne (znajduje to wyraz w przestrzennym segregowaniu więźniów jako osobnych problemów). Obóz zarządza zatem nieomal każdą problematyczną substancją biopolityczną.

Opisany przykład rozciągnięcia obozu poprzez symulację jego porządku w swoim bliskim otoczeniu nazywam „przestrzenią podobozia”. Tu więźniowie wykonują prace zewnętrzne, to tu ogranicza się ruch cywilny i tworzy puste strefy bezpieczeństwa. 
Posiłkując się nastawieniem ekologicznym, umieszczam podobozie na skrajnym obrzeżu instytucji totalnej obozu koncentracyjnego. Następnym kręgiem przestrzeni jest obóz SS, okalający obóz więźniarski, stanowiący ostatni, wewnętrzny krąg obozu. Granice między kręgami wyznaczają druty kolczaste lub inne bariery, w tym lasy, rzeki czy morze, a w ich obrębie znajdują się funkcjonalnie odrębne elementy. Te ostatnie jak część gospodarcza, szpital czy krematorium nazywam enklawami, gdyż ogranicza się do nich dostęp za sprawą właściwych przepustek, a niekiedy wzmacnia izolacyjność poprzez dodatkowe okalanie drutem kolczastym lub oddalanie $\mathrm{w}$ przestrzeni. $\mathrm{Z}$ tego powodu te dziwne przestrzenie, rządzące się jeszcze innym prawem, nazywam enklawami.

Kultura materialna rodzi się z kontaktu człowieka z jego środowiskiem, wyraża się poprzez pozostawianie śladów, na przykład w postaci licznych

\section{Bibliografia}

Archiwum Państwowego Muzeum na Majdanku (APMM) VII/M-497.

Archiwum Państwowego Muzeum na Majdanku (APMM) VII/M-595.

Archiwum Państwowego Muzeum na Majdanku (APMM) VII/M-688.

Appadurai Arjun (1986) Introduction. Commodities and the polittics of value [w:] Arjun Appadurai, ed., The Social life of things. Commodities in cultural perspective. New York: Cambridge University Press, s. 3-63.

Bachmann-Medick Doris (2012) Cultural turns: Nowe kierunki w naukach o kulturze. Przełożyła Krystyna Krzemieniowa. Warszawa: Oficyna Naukowa. przekształceń otoczenia, choć należy pamiętać, że człowiek działa w kontekście narzuconym przez krajobraz materialny, który zwrotnie oddziałuje na kierunek ludzkich wytworów i myśli. Być człowiekiem to posługiwać się rzeczami i poruszać w przestrzeni, które w równym stopniu wytwarzamy, co podlegamy wytwarzaniu przez nie. $Z$ tego powodu zaaranżowanie przestrzenno-materialne obozu koncentracyjnego ma duże znaczenie dla jego funkcjonowania jako organizacji oraz wpływu, jaki wywiera na Goffmanowskich pensjonariuszy. Analiza materiałów biograficznych więźniów obozów ukazuje, że piętno odciśnięte przez inkarcerację wyraża się po wojnie nie tylko w snach, ale również $\mathrm{w}$ kontakcie $\mathrm{z}$ przestrzenią i materialnością (Jagoda, Kłodziński, Masłowski 1984; Posłuszny 2016; 2017c). Każe to myśleć o krajobrazie jako trwałym, a nawet formacyjnym doświadczeniu człowieku, które jako powidok lub echo splata się z jego codziennością.
Baranowska Aneta (2013) Człowiek w instytucji totalnej. Społeczne aspekty stużby polskich żotnierzy poza granicami kraju. Kraków: Zakład Wydawniczy Nomos.

Bartov Omer (1996) Murder in Our Midst: The Holocaust, Industrial Killing, and Representation. Oxford, New York: Oxford University Press.

Baumann Zygmunt (2009) Nowoczesność i zagłada. Przełożył Tomasz Kunz. Kraków: Wydawnictwo Literackie.

Błońska Stefania (1988) Pót roku i pare dni [w:] Krystyna Tarasiewicz, red., My z Majdanka: wspomnienia byłych więźniarek. Lublin: Wydawnictwo Lubelskie, s. 149-158.

Czapliński Przemysław (2016) Poruszona mapa: wyobraźnia geograficzno-kulturowa polskiej literatury przełomu XX i XXI wieku. Kraków: Wydawnictwo Literackie. 
Domańska Ewa (2006) The return to things. „Archaeologia Polona", nr 44, s.171-85.

Domańska Ewa (2010) Muzutman: świadectwo i figura [w:] Łukasz Musiał i in., red., W sprawie Agambena: konteksty krytyki. Poznań: Wydawnictwo Poznańskie, s. 67-86.

Douglas Mary (2007) Czystość i zmaza. Przełożyła Marta Bucholc. Warszawa: Państwowy Instytut Wydawniczy.

Fechner Eberhard, Kranz Tomasz (1996) Proces: obóz na Majdanku w świetle wypowiedzi uczestników rozprawy przed Sąem Krajowym w Düsseldorfie. Lublin: Państwowe Muzeum na Majdanku.

Foucault Michel (2009) Nadzorować i karać: Narodziny więzienia. Przełożył. Tomasz Komendant. Warszawa: Wydawnictwo Aletheia.

Goffman Erving (2011) Instytucje totalne: O pacjentach szpitali psychiatrycznych i mieszkańcach innych instytucji totalnych. Przełożyła Olena Waśkiewicz. Sopot: Gdańskie Wydawnictwo Psychologiczne.

Henare Amiria J. M., Holbraad Martin, Wastell Sari (2007) Thinking through things [w:] Amiria J. M. Henare, Martin Holbraad, Sari Wastell, eds., Thinking through things. Theorising artefacts ethnographically. London, New York: Routledge, s. 1-31.

Hicks Dan (2010) The Material-Cultural Turn: event and effect [w:] Dan Hicks, Mary C. Beaudry, eds., The Oxford Handbook of Material Culture Studies. New York: Oxford University Press, s. 25-98.

Hodder Ian (2012) Entangled: An Archaeology of the Relationships between Humans and Things. Oxford: Wiley-Blackwell.

Horkheimer Max, Adorno Theodor W. (2010) Dialektyka oświecenia. Fragmenty filozoficzne. Przełożyła Małgorzata Łukasiewicz. Warszawa: Wydawnictwo Krytyki Politycznej.

Jagoda Zenon, Kłodziński Stanisław, Masłowski Jan (1984) Więźniowie Oświęcimia. Kraków: Wydawnictwo Literackie.

Kamiński Andrzej Józef (1990) Koszmar niewolnictwa: Obozy koncentracyjne od 1896 do dziś. Analiza. Przełożyli Halina Zarychta, Andrzej Józef Kamiński. Warszawa: Przedświt.

Kiełboń Janina, Balawejder Edward, (red.) (2004) Państwowe Muzeum na Majdanku w latach 1944-1947: wybór dokumentów. Lublin: Państwowe Muzeum na Majdanku.

Knowles Anne Kelly, Jaskot Paul B. (2014) Mapping the SS Concentration Camps [w:] Anne Kelly Knowles i in., eds., Geographies of the Holocaust. Bloomington: Indiana University Press, s. 18-50
Kolen Jan, Renes Johannes (2015) Landscape Biographies: Key Issues [w:] Jan Kolen, Johannes Renes, Rita Hermans, eds., Landscape biographies: geographical, historical and archaeological perspectives on the production and transmission of landscapes. Amsterdam: Amsterdam University Press, s. 21-47.

Kopytoff Igor (2004) Kulturowa biografia rzeczy: utowarowienie jako proces. Przełożyła Ewa Klekot [w:] Marian Kempny, Ewa Nowicka, red., Badanie kultury: Elementy teorii antropologicznej. Kontynuacje. Warszawa: Wydawnictwo PWN, s. 249-274.

Krajewski Marek (2011) Okna władzy, władza okna [w:] Konrad Pustoła, red., Widoki władzy. Warszawa: Bęc Zmiana, s. 13-24.

Krajewski Marek (2013) Sa w życiu rzeczy... Szkice z socjologii przedmiotów. Warszawa: Fundacja Bęc Zmiana.

Krell Alan (2002) The Devil's Rope: A Cultural History of Barbed Wire. London: Reaktion Books.

Kwiatkowski Jan (1966) 485 dni na Majdanku. Lublin: Wydawnictwo Lubelskie.

Mailander Elissa (2015) Female SS Guards and Workday Violance: The Majdanek Concentration Camp, 1942-1944. Przełożyła Patricia Szobar. East Lansing: Michigan State University Press.

Małczyński Jacek (2015) Krajobraz zagłady w perspektywie posthumanistycznej. „Historyka: studia metodologiczne”, z. 45, s. 55-77.

Małczyński Jacek (2017) Historia środowiskowa Zagłady. „Teksty Drugie: teoria literatury, krytyka, interpretacja", nr 2, s. 17-33.

Mańkowski Zygmunt (1991) Obozy hitlerowskie - Majdanek - Lubelszczyzna [w:] Tadeusz Mencel, red., Majdanek 1941-1944. Lublin: Wydawnictwo Lubelskie, s. 19-38.

Marszałek Józef (1987) Majdanek: obóz koncentracyjny w Lublinie. Warszawa: Interpress.

Megargee Geoffrey P., ed. (2009) Encyclopedia of Camps and Ghettos, 1933-1945. Bloomington: Indiana University Press.

Mencel Tomasz, (red.) (1991) Majdanek 1941-1944. Lublin: Wydawnictwo Lubelskie.

Mühlhahn Klaus (2010) The Concentration Camp in Global Historical Perspective. „History Compass”, nr 6, s. 543-561.

Netz Reviel (2009) Barbed Wire: an ecology of modernity. Middletown: Wesleyan University Press. 
Olesiuk Danuta (2011) Urzadzenie przestrzenne Państwowego Muzeum na Majdanku 1944-2010: Plany i realizacja. „Zeszyty Majdanka" nr 25, s. 227-271.

Pajączkowska Agnieszka (2017) Brama [w:] Iwona Kurz i in., red., Ślady Holokaustu w imaginarium kultury polskiej. Warszawa: Instytut Kultury Polskiej UW, s. 23-55.

Panz Mieczysław (1977) Prawo pięści. Warszawa: „Pax”.

Perzanowska Stefania (1970) Gdy myśli do Majdanka wracaja. Lublin: Wydawnictwo Lubelskie.

Posłuszna Joanna, Posłuszny Łukasz (2015) The Aural Landscape of Majdanek [w:] Wojciech Klimczyk, Agata Świerzowska, red., Music and Genocide. Berlin, New York, Oxford: Peter Lang Verlag, s. 105-120.

Posłuszny Łukasz (2015) Materiat, przedmiot i obiekt komemoratywny: Studium chleba w kontekście obozu koncentracyjnego [w:] Elżbieta Wichrowska i in., red., Afektywne historie i polityki pamięci. Warszawa: Instytut Badań Literackich PAN, s. 482-498.

Posłuszny Łukasz (2016) Powroty do normalności więźniów obozów koncentracyjnych. „Spotkania Humanistyczne”, nr 2, s. 71-82.

Posłuszny Łukasz (2017a) Instytucje totalne dzisiaj: stan badań, krytyka, rekonfiguracje. „Studia Socjologiczne”, nr 4, s. 121-145.

Posłuszny Łukasz (2017b) Memory in relation to an object in a context of the materially deprived total institution of the Nazi concentration camp [w:] Barbara Törnquist-Plewa, Niklas Bernsand, Marco La Rosa, eds., In Search of Transcultural Memory in Europe. Lund: The Centre for European Studies, s.125-133.

Posłuszny Łukasz (2017c) Ucieleśniona totalność. Cień obozu w życiu codziennym byłych więźniów [w:] Joanna Posłuszna, red., Psyche - Trauma - Pamięć. Instytucje totalne $i$ ich ślad w pamięci. Kraków: Aureus, s. 25-42.

Posłuszny Łukasz (2019) Materialny świadek, czyli co mówi pasiak obozowy [w:] Katarzyna Grzybowska, Sylwia Papier, Roma Sen- dyka, red., Rzeczowy świadek. Kraków: Wydawnictwo Uniwersytetu Jagiellońskiego, s. 249-270.

Preda Alex (1999) The turn to things. Arguments for a Sociological Theory of Things. „The Sociological Quarterly”, no. 2, s. 347-366.

Schuppli Susan (2012) Najbardziej niebezpieczny film świata. Przełożył Jakub Staniszewski [w:] Krzysztof Gutfrański i in., red., Materialność. Gdańsk: Instytut Sztuki Wyspa, s. 247-284.

Sendyka Roma (2013) Pryzma: zrozumieć nie-miejsce pamięci („non-lieux de mémoire”). „Teksty Drugie: teoria literatury, krytyka, interpretacja", nr 1-2, s. 323-344.

Sofsky Wolfgang (2016) Ustrój terroru. Obóz koncentracyjny. Przełożyła Małgorzata Łukasiewicz. Warszawa: Żydowski Instytut Historyczny.

Spierenburg Pieter (1995) The body and the state. Early modern Europe [w:] Norval Morris, David J. Rothman, eds., The Oxford history of the prison. The practice of punishment in Western society. New York, Oxford: Oxford University Press, s. 49-77.

Thiel Jens (2013) Between recruitment and forced labour: The radicalization of German labour policy in occupied Belgium and northern France. "First World War Studies", nr 1, s. 39-50.

van Alphen Ernst (2004) Zabawa w Holokaust. Przełożyła Katarzyna Bojarska. „Literatura na Świecie”, nr 1-2, s. 217-244.

Wachsmann Nikolaus (2016) KL: Historia nazistowskich obozów koncentracyjnych. Przełożył Maciej Antosiewicz. Warszawa: Świat Książki.

Węgrzyn Łukasz (2015) Granice nazistowskich obozów koncentracyjnych i zagłady na terenie okupowanej Polski. „Studia z Geografii Politycznej i Historycznej", nr 4, s. 277-290.

Wójcik Anna (2012) Informator o zasobie archiwalnym Państwowego Muzeum na Majdanku. Lublin: Państwowe Muzeum na Majdanku.

\section{Cytowanie}

Posłuszny Łukasz (2020) Przestrzenno-materialny krajobraz obozu koncentracyjnego. „Przegląd Socjologii Jakościowej”, t. 16, nr 1, s. 120-142 [dostęp dzień, miesiąc, rok]. Dostępny w Internecie: 〈www.przegladsocjologiijakosciowej.org〉. DOI: http://dx.doi org/10.18778/1733-8069.16.1.08 


\section{The Spatial and Material Landscape of a Concentration Camp}

Abstract: This article focuses on the problem of construction of a total institution by means of analyzing its spatial and material aspects. The subject of the analysis is the concentration camp at Majdanek (KL Lublin), while the biographical approach serves as a theoretical toolbox. The article consists of three main components. It begins with the reconstruction of the research methodology, where I explain the theoretical basis of the work as well as two variants of the way of examining biographies, namely space and items. Here I also define the framework of the research data and the way of interpreting it. Then, I proceed to addressing the problem of the space and the material structure of the concentration camp in Majdanek, which I do by considering the history and spatial organization of concentration camps, their symbolic dimension, and the ecological pattern.

Keywords: space, materiality, landscape, concentration camp, total institution 